\title{
ЗАСТОСУВАННЯ ІНФОРМАЦІЙНО-КОМУНІКАЦЙНИХ ТЕХНОЛОГІЙ ВИКЛАДАЧАМИ ВИЩОЇ ШКОЛИ В НАВЧАЛЬНОМУ ПРОЦЕСІ
}

Ребенок В. М. Застосування інформаційно-комунікачійних технологій викладачами вищої школи в навчальному процесі.

У статті розглянуто прочес використання інформачійно-комунікаційних технологій викладачами вищої школи у навчальному прочесі, який забезпечує передавання знань і доступ до різноманітної навчальної інформачії студентів.

Ключові слова: телекомунікачійний зв'язок, інформачійні технологї навчання, дистанційне навчання, засоби комунікачії.

Ребенок В. М. Применение информационно-коммуникационных технологий преподавателями высшей школь в учебном процессе.

В статье рассматривается проиесс использования информационно-коммуникационных технологий преподавателями высшей школь в учебном прочессе, который обеспечивает передачу знаний и доступ к разнообразной учебной информачии студентов.

Ключевые слова: телекоммуникационная связь, информационные технологии обучения, дистанционное обучение, средства коммуникации.

Rebenok V. Using informatively-communication technologies by the teachers of high school in educational process.

The article reviews the process of using informatively- communication technologies by the high school teachers in the educational process that provides the transmission of knowledge and access to various educational information of students.

Key words: telecommunication connection, information technologies of studies, distance learning, facilities of communication.

Актуальність дослідження. У сучасних умовах інтенсивного розвитку IКТ виникає необхідність у створенні іншого освітнього середовища. Нині актуальним $€$ питання використання програмно-методичних і телекомунікаційних засобів у навчальному процесі загальноосвітньої й вищої школи, зокрема, під час вивчення природничо-математичних і загальнотехнічних дисциплін.

Сучасні мультимедійні комп'ютерні програми й (інформаційні та комунікаційні технологіі) IКТ відкривають доступ до нетрадиційних джерел інформації - електронних підручників, освітніх Web-сайтів, систем дистанційного навчання тощо, це надає можливість підвищити ефективність розвитку пізнавальної самостійної діяльності й надати нові можливості для творчого зростання студентів.

Одна з основних проблем сучасної вищої школи - надання кожному студенту освіти згідно 3 його можливостями, інтересами, вибором, 3 урахуванням перспектив подальшої професійної діяльності та спеціалізованого навчання. Незважаючи на те, що у галузі вищої освіти України вже кілька років упроваджується кредитно-модульна система та наша держава приєдналася до Болонської угоди. 
Аналіз останніх досліджень. Проблемам використання інформаційних технологій у навчальній діяльності присвячено роботи Р. Гуревича, І. Горбунової, В. Ізвозчикова, М. Кадемії, Л. Коношевського, С. Панюкової, I. Роберт, А. Смірнова, В. Сумського.

Роль і місце інформаційних технологій у навчально-пізнавальній діяльності та вплив на психіку людини досліджувалися у роботах Б. Гершунського, В. Рубцова, О. Тихомирова.

Мета статті - проаналізувати особливості застосування інформаційнокомунікаційних технології викладачами вищої школи у навчальному процесі.

Виклад основного матеріалу. Наукові дослідження й досвід практичної роботи засвідчують ефективність розв'язання педагогічних професійних завдань в умовах інформатизації професійного психолого-педагогічного середовища та залежить від таких чинників:

- розуміння фахівцем професійної сутності завдань, які розв'язуються;

- рівня готовності фахівця до професійної діяльності в умовах сучасного інформаційного середовища;

- рівня усвідомлення соціальної важливості педагогічної професійної діяльності.

Аналіз сучасної науково-методичної літератури свідчить про тенденцію все більш широкого використання інформаційних технологій у навчальному процесі ВНЗ. Освіта - це така сфера діяльності людини, яка завжди чутливо реагує на різні способи подання інформації. Саме так до сфери освіти увійшли кіно-, відеофільми, касети з магнітофонними записами, а нині активно впроваджуються ІКТ. Значна кількість досліджень присвячена питанням інформатизації сучасного навчального процесу й основам використання інформаційних технологій під час навчання різних предметів.

Так, I. Мархель пропонує під «інформаційними технологіями навчання» розуміти «комплекс уніфікованих методологічних, психолого-педагогічних i організаційних засобів, призначених для інтенсифікації самостійної пізнавальної діяльності навчання або керування учінням, а також для ігрового людино-машинного розв'язання навчальних і практичних завдань» [5].

Б. Беренфельд виокремлює п’ять функціональних можливостей використання телекомунікацій в освіті:

1. Теледоступ. Доступ до баз даних, різних електронних бібліотек i довідників.

2. Електронні публікації.

3. Телеприсутність.

4. Теленаставник, віртуальний учитель.

5. Телеспівробітництво, робота над проектами.

П. Самойленко зазначає, що IКТ можна застосовувати як: засоби навчання; засоби, що вдосконалюють процес викладання; інструмент пізнання навколишньої дійсності й самопізнання; засоби розвитку особистості того, кого навчають; об'єкт вивчення в межах засвоєння курсу інформатики; інформаційно-методичне забезпечення й управління навчально-виховним 
процесом; засоби комунікації; засоби автоматизації процесу обробки результатів експерименту i управління; засоби автоматизації процесів контролю i коригування результатів навчальної діяльності, тестування i психодіагностики; засоби організації інтелектуального дозвілля [3].

Інформаційні технології Г.Селевка найчастіше застосовуються в навчальному процесі. Інформаційні технології розвивають ідеї програмованого навчання, зорієнтовані на локальні комп'ютери. До апаратних засобів інформаційних технологій відноситься комп'ютер з периферійними пристроями, до програмних засобів відносяться спеціально розроблені дидактичні матеріали.

Моделювання на комп'ютері фізичних процесів, які недоступні для масового спостереження, робить їх наочними $\mathrm{i}$ дає можливість демонструвати широкій аудиторії. Застосування комп'ютерного класу дозволяє в аудиторії розв'язувати фізичні, хімічні та математичні задачі, які практично неможливо запропонувати студентам у межах звичайних практичних занять (наприклад, задачі, які потребують значної кількості складних розрахунків, або задачі, які не мають аналітичного розв'язання i потребують для розв’язання застосування чисельних методів) [4].

Насамперед, IКТ забезпечують можливість проведення дистанційного навчання, показу відео й анімаційних навчальних матеріалів, які знаходяться на різних освітніх серверах, роботи над навчальними телекомунікаційними проектами, асинхронного телекомунікаційного зв'язку, організації дистанційних олімпіад і конкурсів тощо. Під час цього сервери дистанційного навчання забезпечують інтерактивний зв'язок зі студентами через INTERNET, у тому числі, i в режимі реального часу. IКТ забезпечують доступ до баз даних із різних галузей знань.

У результаті студенти, які працюють у такому середовищі, одержують потужну методичну підтримку. Вони набувають необхідних знань, вмінь й навичок у процесі використання обчислювальної техніки для розв'язання цілком конкретних завдань (набір та редагування текстів, створення графічних зображень, робота 3 таблицями тощо). Опановуючи роботу 3 новими програмними продуктами, студенти розвивають навички самоосвіти, вчаться співробітництву 3 колегами, краще розуміють проблеми, що виникають у процесі колективної праці, можуть пояснити товаришам сутність і будову достатньо складних процесів і систем.

Особливої уваги заслуговує опис унікальних можливостей IKT, реалізація яких створює передумови для небувалої в історії педагогіки інтенсифікації освітнього процесу, а також створення методик, орієнтованих на розвиток особистості студентів. Інформаційно-комунікаційні технології забезпечують: негайний зворотний зв'язок між користувачем й IКT; комп'ютерна візуалізація навчальної інформації про об'єкти або закономірності процесів, явищ, що протікають реально, так і віртуальних; архівне зберігання достатньо значних обсягів інформації з можливістю її передачі, а також легкого доступу і звернення користувача до центрального банку даних; автоматизація процесів обчислювальної, інформаційно-пошукової діяльності, а також 
обробки результатів навчального експерименту з можливістю багатократного повторення фрагмента або самого експерименту; автоматизація процесів інформаційно-методичного забезпечення, організаційного управління навчальною діяльністю і контролем за результатами засвоєння знань [2].

Застосування інформаційних технологій в освіті вносить у розвиток людини різні зміни, які відносяться як до пізнавальних, так і до емоційномотиваційних процесів, що впливають на характер людини, під час цього відзначено посилення пізнавальної мотивації студентів у процесі роботи 3 комп'ютером. ІКТ впливають на формування теоретичного, творчого i модульно-рефлексивного мислення студентів. Комп'ютерна візуалізація навчальної інформації робить істотний вплив на формування уявлень, які займають центральне місце в образному мисленні, а образність подання тих або тих явищ і процесів у пам'яті студента збагачує сприйняття навчального матеріалу, сприяє його науковому розумінню.

За умови впровадження комп'ютерної техніки в навчальний процес значно спрощуються такі значні за обсягом роботи організаційного характеру, як розробка i коригування навчальних планів, повсякденна і достовірна інформація про контингент студентів, використання навчальних кабінетів i лабораторій, наявність підручників і навчальних посібників тощо. Безумовно, подібна комп'ютерна мережа має бути інтегрована як методично, так i технологічно [1].

Використання IКТ у навчальному процесі може забезпечити передавання знань і доступ до різноманітної навчальної інформації нарівні, а іноді й інтенсивніше й ефективніше, ніж за традиційного навчання.

Одним із напрямів застосування ІКТ в освіті є дистанційне навчання. Насамперед - можливість залучення кожного студента до активного пізнавального процесу, причому процес не пасивного оволодіння знаннями, а активної пізнавальної самостійної діяльності кожного студента, застосування ними на практиці цих знань і чіткого усвідомлення, де, яким чином і для яких цілей ці знання можуть бути застосовані. Це можливість працювати спільно, у співпраці, у процесі розв'язування різноманітних проблем, виявленняляючи під час цього певні комунікативні уміння, можливість широкого спілкування зі своїми ровесниками 3 інших ВНЗ свого регіону, інших регіонів країни й навіть інших країн світу, можливість вільного доступу до необхідної інформації не лише в інформаційних центрах свого навчального закладу, а й у наукових, культурних, інформаційних центрах усього світу задля формування власної незалежної, проте аргументованої думки з тієї або тієї проблеми, можливості ії всебічного дослідження (вивчення).

Використання телекомунікацій розглядається 3 позиції проектної діяльності (метод проектів), заснованої на пошукових, дослідницьких методах, що дозволяє організовувати різного роду спільні дослідницькі роботи вчителів, студентів, викладачів, науковців із різних навчальних закладів [5].

Внесення до програм навчальних телекомунікаційних проектів упроваджує в структуру навчального предмету нові методи роботи 3 використанням 
інформаційних технологій, створює оперативну підтримку викладачів на робочому місці, умови для дослідницької роботи педагогів, нові засоби дослідницької діяльності як елемент змісту навчання.

Науковці відзначають такі особливості ІКТ, як: багатофункціональність, оперативність, продуктивність, насиченість, можливість швидкої й ефективної творчої самореалізації студентів наявність для них персональної освітньої траєкторії. Це не лише потужний засіб навчання, що дозволяє навчати роботі з інформацією, а з іншого боку, комп’ютерні телекомунікації це особливе середовище спілкування, середовище інтерактивної взаємодії представників різних національних, вікових, професійних та інших груп користувачів незалежно від їхнього місця знаходження. Відрізняючись високим рівнем інтерактивності, комп'ютерні телекомунікації створюють унікальне навчально-пізнавальне середовище, що використовується для розв'язування різних дидактичних завдань (наприклад, пізнавальних, інформаційних, культурологічних тощо) [6].

А. Смірнова наголошує, що створення навчальних програм, навчальних i методичних матеріалів, а також підручників і навчальних посібників нового типу, зорієнтовано на активне використання інформаційних технологій.

Застосування інформаційних технологій у навчальному процесі забезпечує [2]:

- поєднання вербальних методів навчання 3 демонстрацією слайдфільмів дозволяє концентрувати увагу студентів на особливо важливих моментах навчального матеріалу;

- використання технології комп'ютерного підготування студентів до комп'ютерного тестування, контрольних робіт інших видів оперативного контролю знань, дозволяе інтенсифікувати i персоніфікувати процес повторення матеріалу студентами і прискорити адаптацію до віртуального середовища під час наступного комп'ютерного тестування;

- подання навчального матеріалу (лекцій, інтерактивних довідкових матеріалів) у вигляді презентаційних програм у комп'ютерних класах дозволяє студентам використовувати для додаткових занять у години, відведені для самостійної роботи.

Висновки та перспективи подальших розвідок. Використання інформаційних комунікаційних технологій дає можливість значно розширити і поглибити зміст навчання, доступний для всіх вікових груп студентів та суттєво змінити методи й організаційні форми навчання. Це досягається завдяки: а) колосальним можливостям унаочнення змісту, поєднання різних модельностей подання інформації, що стає можливим завдяки використанню комп'ютера; б) наданню студентам можливості користування значним обсягом інформації, вироблення корисних дослідницьких навичок; в) використанню комп'ютерних засобів, побудованих на ідеях штучного інтелекту, зокрема експертних систем, що дозволяє забезпечити глибше засвоєння як декларативних, так і процедурних знань; г) широкому використанню ігрових форм навчання.

Інформаційно-комунікативні технології дозволяють будувати процес 
навчання так: до змісту навчання включається вивчення стратегій розв'язування завдань, у тому числі творчих; забезпечується аналіз і засвоєння студентом своєї власної діяльності; зміст професійного навчання будується з урахуванням реальних виробничих процесів.

Можливість удосконалення та поглиблення засобів інформаційних комунікаційних технологій під час формування професійних знань і вмінь у майбутніх учителів навчального процесу. Відповідно, зростання ролі IКТ у багатьох видах людської діяльності цілком природно сприятиме змінаму системі освіти, які спрямовані на переорієнтацію навчально-виховного процесу 3 репродуктивних механізмів мислення на заохочення творчої активності студентів, що розвиватиметься на базі належного інформаційного забезпечення.

\section{Література}

1. Гуревич Р. С. Інформаційно-телекомунікаційні технології в навчальному процесі та наукових дослідженнях: [навч. посіб. для студ. педагогічних ВНЗ і слухачів інститутів післядипломної педагогічної освіти] / Р. Гуревич, М. Кадемія. - Вінниця : ООО «Планер», 2005. - 365 с.

2. Роберт И. В. Современные информационные технологии в образовании: Дидактические аспекты; перспективы использования / И. В. Роберт. - М. : Школа-Пресс, 1994. - 205 c.

3. Роберт И. В. Информационные технологии в науке и образовании / И. Роберт, П. Самойленко. - М., 1998. - 176 с.

4. Селевко Г. К. Современные образовательные технологии: [учеб. пособие] / Г. К. Селевко. - М.: Народное образование, 1998. - 256 с.

5. Уваров А. Ю. Организация и проведение учебных телекоммуникационных проектов / А. Ю. Уваров. - Барнаул: Изд. БГПИ, 1996. - 96 с.

6. Хуторской А. В. Интернет в школе: [практикум по дистанционному обучению] / А. В. Хуторской. - М. : ИОСО РАО, 2000. - 304 с.

Стаття надійшла до редакції 23.05.2012 р.

УДК 371.132

М. Р. Скоробогатова, кандидат пед. наук,доцент, Таврический национальный университет им. В. И. Вернадского

\section{ПРОФЕССИОНАЛЬНАЯ КОМПЕТЕНТНОСТЬ ПРЕПОДАВАТЕЛЯ ВЫСШЕГО УЧЕБНОГО ЗАВЕДЕНИЯ}

Скоробогатова М. Р. Професійна компетентність викладача вищого навчального закладу.

Сучасному викладачеві вищого навчального закладу недостатньо мати лише знання в певній предметній галузі, навіть на вищому рівні. Для формування професійної компетентності необхідним є постійне самовдосконалення й саморозвиток. Застосування компетентністного підходу дозволить здійснити розроблення методології професійного становлення викладачів вищих навчальних закладів і критеріїв оцінки якості їхньої підготовки.

Ключові слова: компетентність, професійна компетентність, педагогічна компетентність.

Скоробогатова М. Р. Профессиональная компетентность преподавателя высшего учебного заведения. 